\title{
Government Policy And Migration: An Empirical Extension
}

\author{
Richard J. Cebula and Glenn Blomquist*
}

\section{INTRODUCTION}

The empirical research on the migration effects of state and local government policies has been performed by a number of authors in recent years. ${ }^{1}$ These studies by and large have two common traits. First, they tend to stress the impact of a particular government policy, especially welfare benefits. This presents a problem since it neglects other facets of local government policy, such as taxes. ${ }^{2}$ In other words, by concentrating on welfare policy, these studies have not attempted to examine whether would-be migrants examine various non-welfare benefits and/or taxes in their decision calculus. A second trait common to these studies is that they all ignore cost-of-living differentials among different geographic areas. By ignoring such differentials, the consumer-voter is viewed as making locational decisions on the basis of nominal values rather than real values. Hence, the distinct possibility of "money illusion" is introduced since geographic cost-of-living differentials in the United States can be enormous.

Accordingly, the objective of this note is to examine the impact of state and local government policies by investigating a model which (a) views would-be migrants as weighing both the benefits and costs associated with local government units and (b) takes into account cost-of-living differentials among geographic areas.

\section{A MODEL}

To pursue our objectives here, the following equations for white migrants and non-white migrants, respectively, are to be estimated:

$$
\mathrm{M}_{\mathrm{i}}^{\mathrm{W}}=\alpha_{0}+\alpha_{1} \mathrm{Y}_{1}+\alpha_{2} \mathrm{U}_{\mathrm{i}}+\alpha_{3} \mathrm{~W}_{\mathrm{i}}+\alpha_{4} \mathrm{~T}_{\mathrm{i}}+\alpha_{5} \mathrm{E}_{\mathrm{i}}+\mu^{\prime}
$$

and

$$
M_{i}^{n}=b_{0}+b_{1} Y_{1}+b_{2} U_{i}+b_{3} W_{i}+b_{4} T_{i}+b_{5} E_{i}+\mu^{\prime \prime}
$$

where

$\mathrm{M}_{\mathrm{i}}^{\mathrm{W}}=$ gross number of white in-migrants under the age of 55 to area $\mathrm{i}$, 1965-1970, expressed as a percentage of the 1965 white population in area $\mathrm{i}$ under age 55

*Emory University and Illinois State University, respectively. 
$\mathrm{M}_{\mathrm{i}}^{\mathrm{n}}=$ gross number of non-white in-migrants under the age of 55 to area i, 1965-1970, expressed as a percentage of the 1965 non-white population in area $i$ under age 55

$Y_{i}=$ earnings per capita in area $i$, expressed in real terms (see Appendix I)

$\mathrm{U}_{\mathrm{i}}=$ average unemployment rate in area $\mathrm{i}, 1965$

$\mathrm{W}_{\mathrm{i}}=$ average welfare payment per recipient in area $\mathrm{i}$ in the form of aid to families with dependent children (AFDC), 1965, expressed in real terms (see Appendix I)

$T_{i}=$ per capita property tax in area $\mathrm{i}, 1967$, expressed in real terms (see Appendix I)

$\mathrm{E}_{\mathrm{i}}=$ public educational spending per full-time student in area $\mathrm{i}, 1967$, expressed in real terms (see Appendix I)

$\alpha_{0}, \mathrm{~b}_{0}=$ constants

$\mu^{\prime}, \mu^{\prime \prime}=$ error terms

Sufficient data were available for computation and assembly for some 37 metropolitan areas. ${ }^{3}$ The cost-of-living data were obtained from the 1967 and 1969 volumes of the Statistical Abstract of the United States ["Annual Costs of an Urban Intermediate Budget for a 4-Person Family"]. The period under analysis was restricted to the 1965-1970 time period due to the lack of sufficient living-cost data prior to the year $1962 .{ }^{4}$

The migration flow was broken into white and non-white categories. This has been done on the basis of findings of earlier studies indicating that white and non-white migrants behave quite differently. ${ }^{5}$ In point of fact, it is argued below that white and non-white migrants should be expected to react differently to certain public policy variables. The migration flows also excluded all persons age 55 or older. One reason for this is the fact that among the independent variables considered in (1) and (2) is "public education spending." Since most persons age 55 or older do not have school-age children, they could not be expected to be particularly responsive to education policies. A second reason for the exclusion is that persons age 55 or older are unlikely AFDC rceipients.

Conventional migration theory argues that, ceteris paribus, migrants are attracted to areas offering higher real income prospects. Hence, it is hypothesized that $\alpha_{1}>0$ and $\mathrm{b}_{1}>0$. Moreover, except for those migrants whose move is of a mere "job transfer" variety, the higher the unemployment rate in an area, the less attractive the area should be to migrants, ceteris paribus. Hence, it is hypothesized that $\alpha_{2}<0$ and $\mathrm{b}_{2}<0$. This is because higher unemployment rates imply greater risk about obtaining gainful employment, i.e., the expected gain in earnings is less.

As for the policy variables per se, we first consider welfare. Here it is argued that white migrants tend to respond differently to welfare differ- 
entials than non-white migrants. In particular, non-whites on the average have much lower income levels than white counterparts. Hence, on the average, non-whites tend to be more likely candidates to receive welfare than whites. Thus, to the extent that welfare benefits may be viewed by non-whites as a special form of income and/or as a special form of longer-term unemployment compensation, differential real welfare benefit levels can be expected to have a relatively strong impact on non-whites. It is thus argued that $b_{3}>0$. However, since whites on the average tend to have much higher incomes than non-whites and since a much smaller proportion of whites than of non-whites qualifies for welfare, it may be argued that whites are relatively insensitive to real welfare differentials: $\alpha_{3} \sim 0$

As for the property tax, we again can expect whites to react differently than non-whites. In particular, areas with lower property tax levels impose less of a burden on taxpayers than areas with higher tax levels. Hence, white migrants should prefer lower property tax level areas, ceteris paribus: $\alpha_{4}<0 .{ }^{6}$ However, since non-whites on the average tend to own property to a much lesser degree than white counterparts, nonwhites very likely will end up being relatively insensitive to property tax differentials per se, ceteris paribus: $b_{4} \sim 0$. Thus, it is argued that, for the most part, when non-whites pay property taxes, it is included in their rental levels. However, since we are dealing with an analysis couched in real terms, rental levels are already allowed for in the value of the cost of living. Thus, in effect, non-white renters treat property taxes as part of their private cost of living.

Finally, there is the education variable. Areas which commit themselves to higher public education budgets (on a per full-time student basis) are presumably making stronger efforts on behalf of public education than areas with lower such budgets and in fact provide better education. Hence, to the extent that migrants are concerned with the prospect of better public education, areas with higher (real) public education budgets should be the more attractive ones to migrants, ceteris paribus. Thus, it is argued here that, especially in view of the enormous inter-area public educational differentials that exist, $\alpha_{5}>0$ and $b_{5}>0$. This is consistent with the arguments and findings in Pack. ${ }^{7}$

\section{EMPIRICAL RESULTS}

The OLS estimates of equations (1) and (2) are given by (3) and (4), respectively:

$$
\begin{aligned}
& \mathrm{M}_{\mathrm{i}}^{\mathrm{m}}=-6.27825+0.52684 \mathrm{Y}_{\mathrm{i}}-0.34912 \mathrm{U}_{\mathrm{i}}-0.14158 \mathrm{~W}_{\mathrm{i}} \\
& \text { (2.05) } \\
& \text { (1.69) } \\
& -0.15133 \mathrm{~T}_{\mathrm{i}}+0.65805 \mathrm{E}_{\mathrm{i}} \text {, } \\
& \mathrm{DF}=31, \mathrm{R}^{2}=.79
\end{aligned}
$$




$$
\begin{aligned}
& \mathrm{M}_{\mathrm{i}}^{\mathrm{n}}=-5.35063+0.42517 \mathrm{Y}_{\mathrm{i}}+0.15784 \mathrm{U}_{\mathrm{i}}+0.54651 \mathrm{~W}_{\mathrm{i}} \\
& \text { (1.92) (0.97) } \\
& \text { (2.24) } \\
& +0.09504 \mathrm{~T}_{\mathrm{i}}+0.41110 \mathrm{E}_{\mathrm{i}} \\
& \text { (0.88) } \\
& \mathrm{DF}=31, \mathrm{R}^{2}=.72
\end{aligned}
$$

where terms in parentheses are the unsigned $t$-values.

Of the ten coefficients estimated, seven are significant at the .05 level or beyond with the expected sign. The coefficient of determination for the estimate in (3) was .79, so that the model explains nearly four-fifths of the white migration. The coefficient of determination of the estimate in (4) was .72, so that nearly three-fourths of the non-white migration is explained. Correlation coefficients are provided in Appendix II. As shown, there are no major problems.

As for the non-policy variables, equation (3) shows that both real earnings and the unemployment rate were significant determinants of white migration over the 1965-1970 time period. Equation (4) indicates that while real earnings played an important role in influencing non-white migration over the period, the unemployment rate did not.

Of the policy variables, we first consider the welfare variable. In the non-white regression (4), differential welfare levels appear to exercise an important influence. In particular, areas offering higher real welfare benefits seem to be much more attractive to non-white migrants. This result is compatible with earlier studies. However, as equation (3) indicates, real welfare differentials did not exercise an important impact on white migration patterns. This is in contrast to results obtained in several earlier studies of white migration patterns which found a strong, negative relationship. ${ }^{8}$

As for the property tax variable, whites preferred areas with lower such taxes, as hypothesized; however, non-whites were insensitive to property tax levels, also as hypothesized. Finally, we come to the education variable. Equations (3) and (4) indicate that both white and non-white migrants are sensitive to public education policy. ${ }^{9}$

\section{A NOTE ON UNADJUSTED REGRESSIONS}

Before proceeding to the conclusion in this paper, it would seem appropriate to compare the results in estimates (3) and (4) with estimates where the variables are no longer adjusted for the cost of living. This may provide insight into whether there is practical usefulness and need for such adjustment procedures.

Using asterisks $\left({ }^{*}\right)$ to indicate terms which are no longer adjusted for geographic living-cost differentials, the OLS estimates of (1) and (2) respectively become 


$$
\begin{aligned}
& \mathrm{M}_{\mathrm{i}}^{\mathrm{W}}=-5.90281+0.70513 \mathrm{Y}_{\mathrm{i}}^{*}-0.35692 \mathrm{U}_{\mathrm{i}}-0.19025 \mathrm{~W}_{\mathrm{i}}^{*} \\
& \text { (2.06) } \\
& \text { (1.66) }
\end{aligned}
$$

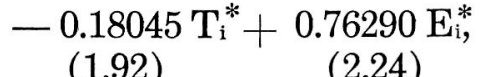

$$
\begin{aligned}
& \mathrm{DF}=31, \mathrm{R}^{2}=.80 \\
& \mathrm{M}_{\mathrm{i}}^{\mathrm{n}}=-5.06123+\underset{(1.90)}{0.49689} \mathrm{Y}_{\mathrm{i}}^{*}+\underset{(0.95)}{\mathrm{O}} .15528 \mathrm{U}_{\mathrm{i}}+\underset{(2.38)}{0.79828 \mathrm{~W}_{\mathrm{i}}^{*}} \\
& +0.10025 \mathrm{~T}_{\mathrm{i}}^{*}+0.49807 \mathrm{E}_{\mathrm{i}}^{*}, \\
& \text { (0.87) } \\
& \mathrm{DF}=31, \mathrm{R}^{2}=.74
\end{aligned}
$$

where terms in parentheses are unsigned $t$-values.

Two major differences between the adjusted regressions in (3) and (4) and the unadjusted regressions in (5) and (6) are

1. The welfare variable in (3) has no real apparent impact on white migration, whereas the welfare variable in (5) has a strong (negative) impact on white migration.

2. The coefficients in (5) are generally higher than those in (3). Hence, the regressions which are not adjusted for geographic cost-ofliving differentials apparently yield biased (upwards) and inconsistent estimators. This attests to the desirability of adjusting for geographic living-cost differentials.

\section{CONCLUSION}

This paper has examined the migration impact of various state and local government policies. It has attempted to provide more meaningful results than earlier studies by examining factors (e.g., earnings) expressed in real terms. This has not been done in previous, related studies. In addition, most other studies of the migration effects of state and local government policies have concentrated on just one fiscal variable (usually welfare) ; the present paper has examined three fiscal variables, variables which enable migrants to evaluate both the costs and the benefits associated with local government policy. Within this framework, it is found that various local government policies apparently did exercise a profound impact on migration over the 1965-1970 time period.

\section{APPENDIX I: THE VARIABLES ADJUSTED FOR LIVING COSTS}

$$
\begin{aligned}
& \mathrm{Y}_{\mathrm{i}}=\frac{1965 \text { Nominal Earnings Per Capita in area } \mathrm{i}}{1965 \text { Cost of Living in area } \mathrm{i}} \\
& \mathrm{W}_{\mathrm{i}}=\frac{1965 \text { AFDC Payment Per Recipient in area } \mathrm{i}}{1965 \text { Cost of Living in area } \mathrm{i}}
\end{aligned}
$$


$\mathrm{T}_{\mathrm{i}}=1967$ Per Capita Property Tax in area $\mathrm{i}$

1967 Cost of Living in area $i$

$\mathrm{E}_{\mathrm{i}}=1967$ Public Education Spending Per Full-Time Student in area i

1967 Cost of Living in area $i$

\section{APPENDIX II: CORRELATION COEFFICIENTS CORRELATION MATRIX}

\begin{tabular}{lrrrrr} 
& $\mathrm{E}_{\mathrm{i}}$ & \multicolumn{1}{c}{$\mathrm{T}_{\mathrm{i}}$} & $\mathrm{W}_{\mathrm{i}}$ & $\mathrm{U}_{\mathrm{i}}$ & $\mathrm{Y}_{\mathrm{i}}$ \\
\hline $\mathrm{E}_{\mathrm{i}}$ & 1.00 & & & & \\
$\mathrm{~T}_{\mathrm{i}}$ & +.51 & 1.00 & & & \\
$\mathrm{~W}_{\mathrm{i}}$ & +.26 & +.31 & 1.00 & & \\
$\mathrm{U}_{\mathrm{i}}$ & +.07 & +.23 & +.37 & 1.00 & \\
$\mathrm{Y}_{\mathrm{i}}$ & +.32 & +.35 & +.25 & -.03 & 1.00
\end{tabular}

FOOTNOTES

1See, e.g., Richard J. Cebula, "Local Government Policies and Migration: An Analysis for SMSA's in the United States, 1965-1970," Public Choice, Fall, 1974, pp. 85-93 and "A Note on Nonwhite Migration, Welfare Levels, and the Political Process," Public Choice, Winter, 1976, pp. 121-123; Gordon F. DeJong and William L. Donnelly, "Public Welfare and Migration," Social Science Quarterly, September, 1973, pp. 329-344; James B. Kau and C. F. Sirmans, "New, Repeat, and Return Migration: A Study of Migrant Types," Southern Economic Journal, October, 1956, pp. 1144-1148; and Paul M. Sommers and Daniel B. Suits, "Analysis of Net Interstate Migration," Southern Economic Journal, October, 1973, 193-201.

2 For an exception, see Richard J. Cebula, "On the Impact of State and Local Government Policies on Human Migration; A Log-Linear Analysis," Review of Regional Studies, Vol. 6, No. 1, 63-68 or Janet R. Pack, "Determinants of Migration to Central Cities," Journal of Regional Science, August, 1973, 249-260.

3These data were gathered from various issues of the Statistical Abstract of the United States and the 1970 Census of the Population (1973a), (1973b). The metropolitan area considered were Atlanta (Ga.), Austin (Tex.), Baltimore (Md.), Baton Rouge (La.), Boston (Mass.), Buffalo (N.Y.), Champaign-Urbana (IIl.), Chicago (Ill.), Cincinnati (Ohio, Ky., Ind.), Cleveland (Oh.), Dallas (Tex.), Dayton (Oh.), Denver (Colo.), Detroit (Mich.), Durham (N.C.), Green Bay (Wis.), Hartford (Conn.), Honolulu (Hawaii), Houston (Tex.), Indianapolis (Ind.), Kansas City (Mo., Kans.), Lancaster (Pa.), Los Angeles (Cal.), Miwaukee (Wis.), Minneapolis-St. Paul (Mn.), Nashville (Tenn.), New York (N.Y.), Orlando (Fla.), Philadelphia (Pa., N.J.), Pittsburgh (Pa.), Portland (Maine), St. Louis (Mo., IIl.), San Diego (Cal.), San Francisco-Oakland (Cal.), Seattle-Everett (Wash.), Washington, D.C. (Md., Va.), and Witchita (Kans.). These were the only such areas having all of the needed data.
4It is now to be pointed out that this model has also been examined using various "quality of life" variables such as climate, and pollution. These variables were dropped from the analysis due to problems of severe multicollinearity.

${ }^{5}$ See, e.g., Andrei Rogers, Matrix Analysis of Interregional Population and Distribution, UCLA Press, 1968 or Sommers and Suits, op. cit.

6 Presumably, of course, the potential impact of property tax differentials on white migration is lessened somewhat by the structure of our federal income tax system.

7See Pack, op. cit.

8See, e.g., Joseph Chao and Stephen M. Renas, "More on Welfare and Migration," $R e$ view of Business and Economic Research, Fall, 1976, pp. 90-91; Pack, op. cit.; or Sommers and Suits, op. cit.

9 Results which are entirely compatible with and quite similar to those in (3) and (4) were obtained in an OLS analysis of net migration. The OLS results are

$$
\begin{aligned}
& \mathrm{NM}_{1}^{\mathrm{w}}=-6.14385+0.58160 \mathrm{Y}_{1}-0.32198 \mathrm{U}_{1} \\
& \text { (2.09) (1.66) } \\
& -0.11918 \mathrm{~W}_{1}-0.16203 \mathrm{~T}_{\mathrm{t}} \\
& \text { (1.04) (1.86) } \\
& +0.63408 \mathrm{E}_{1} \\
& \text { (2.16) } \\
& \mathrm{DF}=31, \mathrm{R}^{2}=.81 \\
& \mathrm{NM}_{1}^{\mathrm{n}}=-4.95910+0.41209 \mathrm{Y}_{1}+0.14368 \mathrm{U}_{1} \\
& \text { (1.96) (1.05) } \\
& +0.55119 \mathrm{~W}_{1}+0.11363 \mathrm{~T}_{1} \\
& \text { (2.26) (0.84) } \\
& +0.40992 \mathrm{E}_{1} \\
& \text { (1.78) } \\
& \mathrm{DF}=31, \mathrm{R}^{2}=.76
\end{aligned}
$$

where terms in parentheses are $t$-values and where $\mathrm{NM}_{1}=$ net white in-migration rate of persons under age 55 to area $\mathrm{i}$ and $\mathrm{NM}_{1}=$ net nonwhite in-migration rate of persons under age 55 to area $i$. The time period again is 1965 to 1970 . 